\title{
PERFORMANCE EVALUATION OF TRACTOR OPERATED
}

\section{SUGARCANE STUBBLE SHAVER}

\section{VINAYAKA $^{1}$, BEERGE RAMESH $^{2} \boldsymbol{\&}$ SUNIL SHIRWAL ${ }^{3}$}

${ }^{I}$ Testing Engineer, Department of Farm Machinery and Power Engineering, College of Agricultural Engineering, Raichur, Karnataka, India

${ }^{2}$ Assistant Professor, Department of Farm Machinery and Power Engineering, College of Agricultural Engineering, Raichur, Karnataka, India

${ }^{3}$ Senior Testing Engineer, Department of Farm Machinery and Power Engineering,

College of Agricultural Engineering, Raichur, Karnataka, India

\section{ABSTRACT}

Sugarcane stubble shaving is an important field operation followed for harvesting of sugarcane crop in ratoon management practice. Sugarcane, apart from being a vital source of sugar provides a fair amount of raw material for sugarcane industries. In ratoon management practice, where sugarcanes are harvested at just above the ground level to allow the sprouting of stems for next season, tractor operated stubble shaver is a suitable machine in harvesting operation. A sugarcane stubble shaver was procured from market and was evaluated for its field performance at the College of Agricultural Engineering, Raichur. During the harvesting operation by stubble shaver for 22.5 h, various field performance parameters were evaluated. The average field capacity, mass of stubble in $10 \mathrm{~m}$ strip after the slashing operation, mass of stubble per unit area were recorded as 0.44 to $0.48 \mathrm{ha} \mathrm{h}^{-1}, 12.35$ to $14.10 \mathrm{~kg}, 1.12 \mathrm{to} 1.45 \mathrm{~kg} \mathrm{~m}^{-2}$ respectively. The average stubble height after the operation was recorded as 32 to $43 \mathrm{~mm}$. The average wheel slippage was observed as 4.1 to 7.3 per cent. The fuel consumption of tractor while operating with stubble shaver was observed as 4.4 to $5.2 \mathrm{~L} \mathrm{~h}^{-1}$. The results of wear analysis of cutting blades on dimensional basis and mass basis were recorded as 0.02 to 0.18 and 0.12 to 0.25 per cent, respectively. The hardness of cutting blade was observed to be 29.2 to 33.1 HRC. Hence, the performance of sugarcane stubble shaver in field was satisfactory and was duly recommended for use in ratoon management practice, as it reduces the cost of operation and drudgery involved in manual harvesting.

KEYWORDS: Ratoon Management, Stubble Shaver, Field Capacity, Wear Analysis \& Hardness

Received: Jun 19, 2017; Accepted: Jul 13, 2017; Published: Jul 17, 2017; Paper Id.: IJASRAUG201728

\section{INTRODUCTION}

Sugarcane is one of the major cash crops cultivated in India. It is a vital source of sugar. Apart from being source of sugar, it is a good raw material for the production of white sugar, jaggery and khandsari. It is also used for extraction of juice for beverage purpose. Sugarcane shares about 7 per cent of the total value of agriculture output and it has occupied about 2.6 per cent of India's gross cropped area during 2006-07. India stands second in the world after Brazil, in the production of sugarcane. Sugarcane provides raw material for the second largest agro-based industry after textile. About 527 working sugar factories with total installed annual sugar production capacity of about 242 lakh tonnes are located in India during 2010-11. Karnataka is one of the major states in which sugarcane is cultivated. It is grown in the districts of Belgaum, Bagalkot, Bidar, Mandya, Gulbarga and Bijapur. Hence, there is a wide scope to mechanize the production technique, as it would save energy, cost of tillage operations and saving in planting 
material. It gets benefit of residual manure and moisture. Ratoon crop matures earlier and gives more or less same yield as of planted cane. However, taking more than one ratoon will increase the incidence of pests and diseases and deterioration of soil takes place. Ratooning is usually practiced by harvesting the sugarcanes just above the ground level. Manual labour is engaged in this process. Due to lack of availability of human power and drudgery involved in the operation, there is a wide scope to popularize the tractor operated sugarcane stubble shaver for harvesting of sugarcane in ratoon cropping. Sugarcane stubble shaver, also called as stubble shaver is a vital machine to practice ratoon cropping in sugarcane cultivation. A tractor operated stubble shaver has been procured and evaluated for its performance in the field at the College of Agricultural Engineering, UAS, Raichur.

The stubble shaver has two to four blades arranged on a rotor, which gets the rotational power from PTO of the tractor through a set of gear arrangement. The blades are designed to cut the canes just above the ground level without disturbing the adjacent rows. It has two ridgers on either side of the machine to form ridges to the sides and also to control the height of cutting.

\section{MATERIALS AND METHODS}

A unit of tractor operated stubble shaver was directly procured from the market. The stubble shaver had two to four blades arranged on a common rotor, which gets the rotational power at right angles from PTO of the tractor through bevel gear arrangement. The blades are designed to cut the canes just above the ground level without disturbing the adjacent rows. It has two ridgers on either side of the machine to form ridges to the sides and also to control the height of cutting. A standard hitch pyramid was attached at the front of the machine. The schematic diagram of the tractor operated sugarcane stubble shaver is presented in Fig.1 and the detailed specifications of the machine are depicted in the Table 1.

Table 1: Specifications of Sugarcane Stubble Shaver

\begin{tabular}{|c|c|c|}
\hline S. No. & Particulars & Observed Values \\
\hline 1. & Type & Tractor operated \\
\hline 2. & Working width, $\mathrm{mm}$ & 1020 \\
\hline \multicolumn{3}{|c|}{ Details Of Gear Box: } \\
\hline & Type & SG cast iron gear box \\
\hline & Number of teeth on bevel pinion & 22 \\
\hline & Number of teeth on crown gear & 14 \\
\hline & Gear ratio & $1: 1.57$ \\
\hline \multicolumn{3}{|c|}{ Details Of Rotor: } \\
\hline & Type and Size (Diameter x Thickness), mm & $360 \times 12$ \\
\hline & Rotational speed of rotor corresponding to standard PTO speed, rev $\min ^{-1}$ & 848 \\
\hline \multicolumn{3}{|c|}{ Cutting Blade: } \\
\hline & Numbers & Four \\
\hline & Material & Boron steel \\
\hline & Overall thickness, $\mathrm{mm}$ & 6 \\
\hline & Thickness of bevelled edge, $\mathrm{mm}$ & 3 \\
\hline \multicolumn{3}{|c|}{ Overall Dimensions: } \\
\hline & Length, mm & 1260 \\
\hline & Width, mm & 1290 \\
\hline & Height, mm & 1100 \\
\hline
\end{tabular}

\begin{tabular}{|l|l|}
\hline 1 & Main Frame \\
\hline 2 & Gear box \\
\hline 3 & Ridger \\
\hline 4 & Hitch pyramid \\
\hline
\end{tabular}




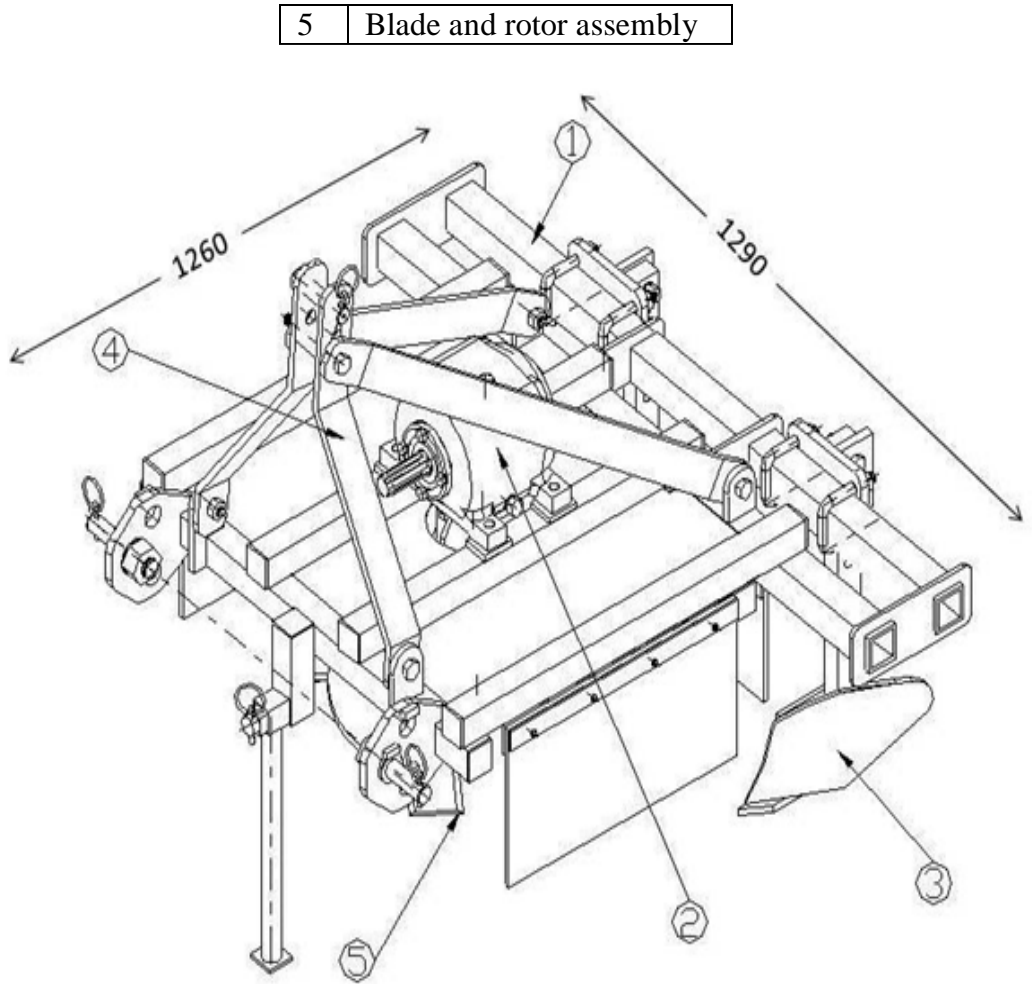

Figure 1: Schematic View of Sugarcane Stubble Shaver

\section{Field Performance Evaluation}

The stubble shaver was evaluated for its performance in the field. It was operated in sugarcane field during harvesting stage for $22.5 \mathrm{~h}$. The wear analysis of all four cutting blades was carried out on dimensional basis as well as on mass basis.

\section{Variation of Draft with Speed of Operation}

Draft requirement of tractor operated stubble shaver was measured at six different speeds varying between 4 and 5 $\mathrm{kmh}^{-1}$ and the observed results were graphically represented.

\section{Hardness of Blade}

The hardness of the blade was tested by Brinell hardness test procedure and the results were compared with the Bureau of Indian Standard code (IS: 1511-1979).

\section{Chemical Composition of Blade}

The material of blade was got analysed for chemical composition and the results were compared with Bureau of Indian Standard code (IS: 1511-1979).

\section{RESULTS AND DISCUSSIONS}

The sugarcane stubble shaver was operated for $22.5 \mathrm{~h}$ in black cotton soil for harvesting sugarcane. The results of field performance evaluation are given in Table 2. The average field capacity of the machine was recorded as 0.44 to 0.48 ha $\mathrm{h}^{-1}$ when the speed of operation ranged between 4.35 and $4.69 \mathrm{kmh}^{-1}$. The mass of stubble in $10 \mathrm{~m}$ strip after the 
slashing operation was recorded as 12.35 to $14.10 \mathrm{~kg}$. The average stubble height after the operation was recorded as 32 to $43 \mathrm{~mm}$. The mass of stubble per unit area after operation was recorded as 1.12 to $1.45 \mathrm{~kg} \mathrm{~m}^{-2}$. The average wheel slippage was observed as 4.1 to 7.3 per cent. The fuel consumption of tractor while operating with stubble shaver was observed as 4.4 to $5.2 \mathrm{~L} \mathrm{~h}^{-1}$.

The per cent wear of blades on dimensional basis as well as mass basis was calculated. The wear of blades on dimensional basis was found out by measuring the dimensions of blade, at five distinct places spaced at $48 \mathrm{~mm}$ denoted as A, B, C, D and E in Fig.2, before and after the operation. Results of wear analysis are depicted in Table 3a and 3b, respectively. The hourly percentage wear of blade on dimensional basis and mass basis were recorded as 0.02 to 0.18 and 0.12 to 0.25 per cent, respectively.

\section{Variation of Draft with Speed of Operation}

The stubble shaver was operated at five different speeds varying between 4 and $5 \mathrm{kmh}^{-1}$ at the intervals of $0.2 \mathrm{kmh}^{-1}$. Observed values of draft at different speeds have been tabulated in Table 4 and also shown graphically in Fig. 3.

Table 2: Summary of Field Performance Test

\begin{tabular}{|c|c|c|}
\hline S. No & Parameter & Range \\
\hline 1. & Tractor used & Mahindra \& Mahindra 595 DI \\
\hline 2. & Gear & $\mathrm{L}-2$ \\
\hline \multirow[t]{3}{*}{3.} & Engine speed & \\
\hline & No load & 2111 to 2117 \\
\hline & On load & 1965 to 2002 \\
\hline 4. & Avg. Forward speed, $\mathrm{kmh}^{-1}$ & 4.35 to 4.69 \\
\hline 5. & Avg. Width of cut, mm & 1016 to 1020 \\
\hline \multirow[t]{3}{*}{6.} & Avg. Stubble height, mm & \\
\hline & Before operation & 180 to 210 \\
\hline & After operation & 32 to 43 \\
\hline \multirow[t]{3}{*}{7.} & Average mass of stubble, $\mathrm{kg} \mathrm{m}^{-2}$ & \\
\hline & Before operation & 2.35 to 3.12 \\
\hline & After operation & 1.12 to 1.45 \\
\hline 8. & Mass of stubble in $10 \mathrm{~m}$ (after operation), $\mathrm{kg}$ & 12.35 to 14.10 \\
\hline 9. & Avg. wheel slippage, per cent & 4.1 to 7.3 \\
\hline 10. & Avg. Area covered, ha h ${ }^{-1}$ & 0.44 to 0.48 \\
\hline 11. & Time required for one ha, $\mathrm{h}$ & 2.33 to 2.60 \\
\hline 12. & Avg. missed stubble, per cent & 0 to 4.3 \\
\hline \multirow[t]{3}{*}{13.} & Fuel consumption, & \\
\hline & $\mathrm{L} \mathrm{h}^{-1}$ & 4.4 to 5.2 \\
\hline & $\mathrm{L} \mathrm{ha}^{-1}$ & 33.84 to 40.0 \\
\hline
\end{tabular}

Table 3a: Wear Analysis of Blade on Dimensional Basis

\begin{tabular}{|c|c|c|c|c|c|c|c|c|c|c|c|c|c|c|c|c|c|c|c|c|}
\hline \multirow{3}{*}{ S. } & \multicolumn{10}{|c|}{$\begin{array}{l}\text { Blade Width At Every } 48 \mathrm{Mm} \text { From Top End } \\
\text { (Mm) }\end{array}$} & \multicolumn{10}{|c|}{ Percentage Wear, \% } \\
\hline & \multicolumn{5}{|c|}{ Initial } & \multicolumn{5}{|c|}{ Final } & \multicolumn{5}{|c|}{ After $22.5 \mathrm{H}$} & \multicolumn{5}{|c|}{ Per Hour } \\
\hline & $\mathrm{A}$ & $\mathrm{B}$ & $\mathrm{C}$ & $\mathrm{D}$ & $\mathrm{E}$ & $\mathrm{A}$ & $\mathrm{B}$ & $\mathrm{C}$ & $\mathrm{D}$ & $\mathrm{E}$ & $\mathrm{A}$ & $\mathrm{B}$ & $\mathrm{C}$ & $\mathrm{D}$ & $\mathrm{E}$ & $\mathrm{A}$ & $\mathrm{B}$ & $\mathrm{C}$ & $\mathrm{D}$ & $\mathrm{E}$ \\
\hline 1 & 87 & 88 & 88 & 89 & 69 & 84 & 83 & 85 & 86 & 69 & 3.45 & 5.68 & 3.41 & 3.37 & 0.00 & 0.15 & 0.25 & 0.15 & 0.15 & 0.00 \\
\hline 2 & 87 & 87 & 87 & 84 & 70 & 85 & 85 & 84 & 82 & 69 & 2.30 & 2.30 & 3.45 & 2.38 & 1.43 & 0.10 & 0.10 & 0.15 & 0.11 & 0.06 \\
\hline 3 & 86 & 86 & 88 & 87 & 70 & 83 & 82 & 84 & 85 & 70 & 3.49 & 4.65 & 4.55 & 2.30 & 0.00 & 0.16 & 0.21 & 0.20 & 0.10 & 0.00 \\
\hline 4 & 85 & 86 & 85 & 84 & 69 & 82 & 83 & 82 & 81 & 69 & 3.53 & 3.49 & 3.53 & 3.57 & 0.00 & 0.16 & 0.16 & 0.16 & 0.16 & 0.00 \\
\hline & & & & & & & rag & $\mathrm{Pel}$ & Cen & We: & & & & & & 0.14 & 0.18 & 0.17 & 0.13 & 0.02 \\
\hline
\end{tabular}

Table 3b: Wear Analysis of Blade on Mass Basis

\begin{tabular}{l|l|l|l|} 
S. No. & Initial Mass (G) & Final Mass (G) & Percentage Wear \\
\hline
\end{tabular}




\begin{tabular}{|c|c|c|c|c|}
\hline & & & After 22.5 H & Per Hour \\
\hline 1 & 1113 & 1096 & 4.22 & 0.19 \\
\hline 2 & 1107 & 1039 & 2.62 & 0.12 \\
\hline 3 & 1112 & 1101 & 4.86 & 0.22 \\
\hline 4 & 1103 & 1087 & 5.53 & 0.25 \\
\hline
\end{tabular}

\section{Hardness of Blade}

Hardness of the cutting blades was tested by Brinnell Hardness testing method and the results are shown in Table 5. The hardness of blades varied from 29.2 to 33.1 HRC, against the requirement of 35 to $50 \mathrm{HRC}$ as per IS: 1511-1979.

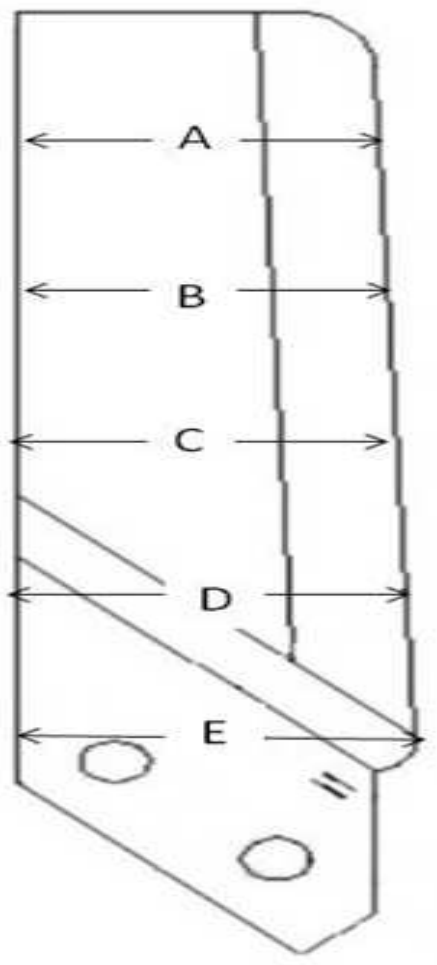

Figure 2: Reference Places on the Stubble Shaver Blade to Calculate the Per Cent Wear on Dimensional Basis

Table 4: Observed Values of Draft at Different Speeds of Operation

\begin{tabular}{|c|c|c|}
\hline S. No. & Speed, $\mathbf{~ k m h}^{-1}$ & Draft, kgf \\
\hline 1. & 4.0 & 399 \\
\hline 2. & 4.2 & 383 \\
\hline 3. & 4.4 & 388 \\
\hline 4. & 4.6 & 379 \\
\hline 5. & 4.8 & 397 \\
\hline 6. & 5.0 & 388 \\
\hline
\end{tabular}




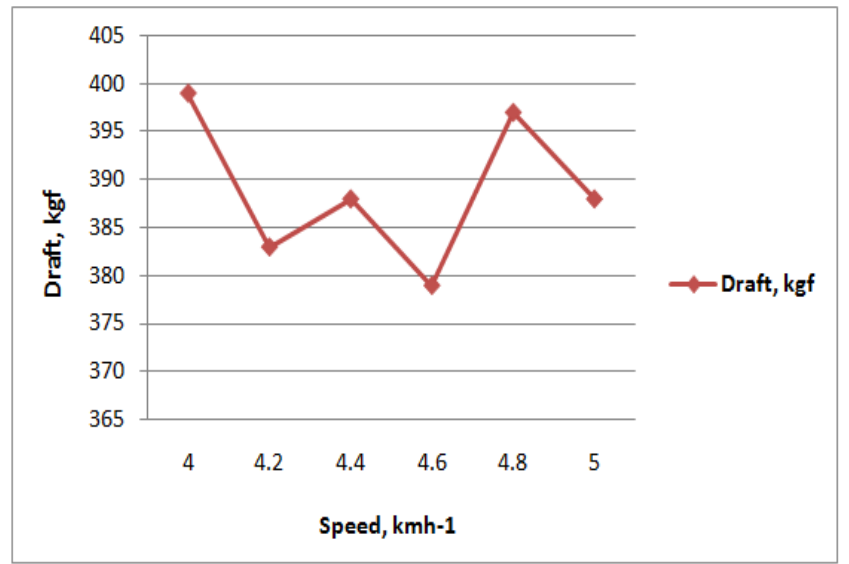

Figure 3: Variation of Draft with Speed of Operation

Table 5: The Surface Hardness of Blade was Recorded as Under

\begin{tabular}{|c|c|c|c|}
\hline \multirow[b]{2}{*}{ S. No. } & \multicolumn{2}{|l|}{ Hardness (Hrc) } & Remarks \\
\hline & As Per IS: 1511-1979 & As Observed & \multirow{5}{*}{ Does Not Conform } \\
\hline 1 & \multirow{4}{*}{$35-50$} & 29.2 & \\
\hline 2 & & 31.5 & \\
\hline 3 & & 33.1 & \\
\hline 4 & & 30.6 & \\
\hline
\end{tabular}

\section{Chemical Composition of Blade}

The cutting blade was tested for its chemical composition in laboratory and the results are depicted in Table 6 . The results have shown that the contents of carbon, phosphorous and sulphur were on par with the requirement of relevant BIS code (IS: 1511-1979) whereas the contents of Manganese and Silicon did not conform to the requirement.

Table 6: Chemical Composition of Cutting Blade

\begin{tabular}{|l|c|c|l|}
\hline \multirow{2}{*}{ Constituents } & As Per IS: 1151- 1979 & \multirow{2}{*}{ Chemical Composition as Observed, \% } & Conformity To IS \\
\cline { 2 - 4 } & Carbon Steel, \% & 0.75 & Conforms \\
\hline Carbon $(\mathrm{C})$ & $0.60-0.90$ & 0.59 & Does not conform \\
\hline Manganese (Mn) & $0.10-0.35$ & 0.34 & Does not conform \\
\hline Silicon $(\mathrm{Si})$ & $0.50-0.80$ & 0.030 & Conforms \\
\hline Phosphorous (P) & $0.05(\mathrm{Max})$ & 0.022 & Conforms \\
\hline Sulphur (S) & $0.05(\mathrm{Max})$ & & \\
\hline
\end{tabular}

\section{CONCLUSIONS}

The field performance of sugarcane stubble shaver has provided a vital space for the Research and development in sugarcane ratoon management. From the present investigation, it can be concluded that the field performance of sugarcane stubble shaver for ratoon cropping was satisfactory. The field capacity, uniformity of stubble height and per cent missed stubble were better compared to manual harvesting. It was observed that draft of the implement has shown higher degree of variation with speed of operation. The speed range with minimum draft was found difficult to select with such erratic variation. The hardness and chemical composition of cutting blades were not completely on par with the requirement of relevant Indian Standard. The machine can be made more utilizable by making arrangements to windrow the cut sugarcane, and by making necessary modifications in ridger attachment to suit the working environment and soil 
conditions.

\section{REFERENCES}

1. Anonymous. 2013. Status paper on sugarcane. Directorate of Sugarcane Development, Government of India, Ministry of Agriculture, pp: 1-16.

2. Prasanna, S. M. and Pattar, P. S. 2014. Successful ratoon management in sugarcane. Journal of Agriculture and Allied Sciences, 3(4): 39-47.

3. Sakin, O. H., Deshmukh, V. D., Turbatmath, P.A., Bastewad, T.B., Deshpande, J. S., Sangalikar, R.V., and Thokale, P. J. 2016. Development and performance evaluation of Low-hp tractor operated stubble shaver-cum-off barring implement with fertilizer metering for sugarcane crop. International Journal of Technology Enhancements and Emerging Engineering Research, 4(2): $1-5$.

4. Thorburn, P. J., Horan, H. L. and Biggs, J. S. 2004. The impact of trash management on sugarcane production and nitrogen management: A simulation study. Proceedings of Australian Society of Sugar Cane Technology, 26: 1-12.

5. Yadav, R. N. S., Yadav, S. and Tejra, R. K. 2003. Labour saving and cost reduction machinery for sugarcane cultivation. Sugar Tech., 5(1): 7-1 
